\title{
The Impact of Socio-Political and Economic Environments on Private Sector Participation in Energy Infrastructure Delivery in Ghana
}

\begin{abstract}
Purpose: Investment in power and electricity generation to replace aging infrastructure with new represents a major challenge for developing countries. This paper therefore seeks to examine infrastructure projects' characteristics and how socio-political and economic investment environments interplay to influence the degree of private sector participation (PPP) in infrastructure delivery in Ghana.

Design: Using World Bank Public-Private Infrastructure Advisory Facility (PPIAF) and Private Participation in Infrastructure (PPI) Project Database data from 1994 to 2013, binary logistic regression was used to: i) determine the probability of a higher or lower degree of private sector participation; and ii) examine the significance of factors that are determinants of private investments.

Findings: The findings reveal that the private sector is more likely to invest in a higher degree of PPP infrastructure projects through greenfield and concession vehicles as opposed to management and leasing contracts. From the extant literature, drivers of private sector participation included infrastructure project characteristics and the socio-economic-political health of the host country. However, the significance, direction and magnitude of these drivers vary.

Originality: This paper identifies investment drivers to PPP advisors and project managers and seeks to engender discussion amongst government policy makers responsible for promoting and managing PPP projects. Direction for future work seeks to explore competitive routes to infrastructure debt and equity finance options that finance energy projects.
\end{abstract}

Keywords: private sector participation, public-private partnership, energy infrastructure projects, PPP contracts.

\section{INTRODUCTION}

Global demand for electricity is almost double that of the total energy consumption, and this challenging situation is exacerbated by the investment needed to replace ageing power sector infrastructure (EC, 2011). In developing countries, an estimated $\$ 5$ trillion of investment is needed 
to meet the expected demand for electricity by 2030 , with more than $\$ 2$ trillion needed for new generation capacity alone (Woodhouse, 2005; Tohmatsu, 2003). This investment shortfall has created a deficit in energy and consequently, lethargic economic growth across the African continent (UNECA, 2011). Traditionally, public funds (mainly taxes and rates) and donor support have provided major sources of finance for infrastructure development in middle-income and lowincome developing countries (Owusu-Manu et al., 2008; PSIRU, 2012). However, such funds are inadequate and have failed to resolve the energy infrastructure deficit because this complex problem encapsulates both structural and political attributes. The extant literature reports that structural attributes include inappropriate policy framework regulations (including tariff setting and procurement), while political attributes include inefficient public institutions for the management of infrastructure, limited political will to prioritize energy development, and prevailing political instability (UNECA, 2011; OECD, 2012).

The electricity market's weak financial condition stems from under-pricing of electricity tariffs and inefficiencies in revenue collection, which in combination have made power projects unattractive to private investors (World Bank, 2011). In Ghana, the underdeveloped and shallow nature of the capital market affords limited alternatives for investors to obtain long-term 'affordable' finance for infrastructure projects (Irving and Manroth, 2009; UNECA, 2011). Independent Power Producers (IPPs) have hitherto sought international investment even though accompanying foreign exchange rates represent a significant risk. These systemic issues have reduced private participation in energy infrastructure development and have accounted for high electricity tariffs. The conundrum for many developing countries is how to create a safe investment environment that generates affordable electricity (ibid).

Innovative financing approaches represent a possible solution for both current and future infrastructure needs (Badu et al, 2012). Public Private Partnership(s) (PPP(s)) represents one such approach and provide: alternative sources of capital; a vehicle for improving the efficiencies in public project investment delivery; and an opportunity to enhance project management expertise (Moszoro and Krzyzanowska, 2007). By combining public needs with private capability and resources, PPPs represent a more politically palatable option than privatization (UNECA, 2011). To date, empirical research has focused on the risk factors (i.e. political, legal and economic) at a 
national level as individual determinants of PPPs (c.f. Basilio, 2010; Albalate et al., 2012; Hammami et al., 2006; Ismail, 2013) and the critical success factors for the implementation of PPPs in infrastructure projects (c.f. Ogunsanmi, 2014; Zagozdzon, 2013). Limited research has been undertaken to explore how characteristics of infrastructure projects and the socio-political and economic investment environments interact at a holistic level to influence the degree of private sector participation. This research therefore seeks to investigate these interrelationships within Ghana's energy infrastructure market as a means of generating greater understanding of them. Emergent new knowledge generated will afford crucial information for PPP advisors, project managers and government officials who strive to reform energy markets and concomitant infrastructure development.

\section{LEGAL FORMS AND DEGREE OF PRIVATE PARTICIPATION IN INFRASTRUCTURE DELIVERY}

PPPs have provided a catalyst for stimulating greater private sector participation in the provision of public services (Demirag et al., 2010). PPPs legally bind public and private sector entities and this arrangement facilitates a conduit, or point of entry, for private investors to participate in infrastructure delivery (Peirson and McBride, 1996 in Grimsey and Lewis, 2002). Contractual arrangements for PPPs are classified into five thematic groupings, namely: i) management contracts; ii) leasing contracts; iii) concessions; iv) greenfield projects; and v) divestiture/ privatization. Each variant contains sub-types according to the level of private sector participation and the degree of risk associated with the contract (UNECA, 2011).

Under management contracts, the private company assumes responsibility for the operations and maintenance of the public enterprise for an agreed contract fee and over a specific period (normally 3-5 years) (c.f: ESCAP, 2011). Ownership, investment decisions, and financial responsibilities remain with the public sector (Pessoa, 2008). The Built-Lease and Operate (BLO) organization provides an example of a typical management contract used in the utilities sector (i.e. electricity, gas, water, transport and telecommunications) (Devapriya, 2006). For leasing contracts, a private company acquires temporary ownership of the asset over a specific period in return for revenues. Responsibility for operating the asset is assumed, including any associated commercial risks, typically over a period of 10-15 years (Ogunsanmi, 2014). Under concession, a public entity owns 
the assets but operations, maintenance and investment decisions are contracted out to a private company; ownership of the asset reverts back to the public sector after a specific 25-30 years period of time (IBRD/World, 2009). This contractual arrangement may release efficiency gains in both operations and investment but requires considerable commitment and regulatory capacity for its sustainability (Pessoa, 2008). Under the greenfield arrangement, the private investor finances, builds and operates a new project for a specific period and this remains in private ownership (Albalate et al., 2011). The private investor absorbs the commercial risk while the political and exchange rate risks are shared with the public sector (Pessoa, 2008). Such projects are myriad but the most common is Built, Own and Transfer (BOT) where asset ownership is transferred to the government at the end of the concession period (ibid). Because of the high initial investment and lengthy concession periods involved (15-30 years), an appropriate risk distribution strategy between parties is required. Other forms of greenfield projects include: Build-Own-Operate (BOO); Build-Own-Operate-Transfer (BOOT), Design-Build-Operate (DBO), Design- BuildFinance-Operate (DBFO) and Build-Lease-Transfer (BLT). Divestiture, otherwise known as privatization, is where a public enterprise (or part(s) thereof) is sold to a private entity in exchange for an equity stake (Devapriya, 2006). The private investor acquires ownership of the public assets and assumes all related risks (Albalate et al., 2011). This contractual arrangement provides potential high efficiency gains but requires a solid regulatory environment and careful preparation to be successful (Pessoa, 2008). Divestiture can be partial divestiture or joint venture, where part of an asset is sold to the private sector or the government and a private entity jointly fund a new asset (UNECA, 2011; Devapriya, 2006). The duration of this contract is usually indefinite but it may be limited under license (Pessoa, 2008).

From this synthesis of literature, it is appropriate to hypothesize that:

Hypothesis 1: The degree of private sector participation in an energy infrastructure project delivery is significantly dependent on: (H1a) ownership level; (H1b) size of investment; (H1c) the power sector; (H1d) generation segment; and (H1e) revenue source.

The type of PPP arrangement entered into determines the degree of private sector participation; the extent of investments; sharing of risk; and other requirements needed to execute the project 
successfully. The degree of participation is theoretically classified (for the purposes of this research) as either 'higher' or 'lower'. The higher the risk that the private investor assumes, the higher the intensity of participation and the greater the anticipated profitability from such risk taking (refer to Figure 1). Concessions, greenfield projects and divestiture are classified as higher intensity forms of PPP contracts, while management and leasing contracts are regarded as lower intensity forms of PPP contracts.

\section{PRIVATE SECTOR INVESTMENTS AND THE SOCIO-POLITICAL AND ECONOMIC ENVIRONMENTS}

Attracting private sector investors to PPP contracts and their successful implementation requires both a supportive policy/ regulatory framework and a competitive investment climate (Alexander et al., 1996; and Kirkpatrick and Parker, 2004). Robust economic regulations ensure that the interests of all parties involved (public, private and the end user) are protected (World Bank, 1994). Unbundling the once monopolized state utilities, and establishing independent regulatory regimes to oversee them, brought about effective competition and efficiency within electricity markets (Joskow and Schmalensee, 1983; Newbury, 2000; Jamasb and Pollitt, 2005). Competition is a prerequisite for markets to work efficiently because it lowers costs and improves product and service quality (Austvik, 2009). An environment of macroeconomic and political stability, policy credibility and the existence of a sound regulatory framework are necessary for lowering the perceived risk of expropriation (c.f: Kerf et al., 1998). However, within developing countries, social regulatory policies that are geared to support election campaigns are often unpalatable to private investors. To protect investors, regulations can be implemented to protect the rate of return on investments (World Bank, 1994; Burns and Riechmann, 2004). Yet, despite the palpable benefits of PPPs, efforts to deregulate are often met with skepticism, derision and strong resistance (Balouga, 2012).

Establishing central agencies that have the financial and technical capacity to oversee the management of PPP projects is a prerequisite to the successful implementation of PPP contracts (Pistor, 2000). Such institutions facilitate transparency in management accounting and financial reporting - essential for performance measurement during the implementation and evaluation of PPP contracts (Demirag et al., 2010). The effectiveness of regulatory institutions depends upon 
the structure and process of regulation, key aspects of which are: the independence and competence of regulatory agencies; the transparency and openness of the regulatory process; the existence of formal oversight and timely judicial review; and the country's stability and reputation for respecting private property rights (Smith, 1997; Pargal, 2003; Noll, 2000). Effective regulations and institutions provide confidence and assurance for the protection of private sector investment and reduce the risk faced by the host country (Parker and Hartley, 2003).

A country's economic stability (or 'pull factor') represents a specific portfolio of investment risks and returns which may, or may not, attract foreign investment (Mody et al., 2001; Ahmed and Zlate, 2013; Dua and Garg, 2013; c.f. Taylor and Sarno, 1997; Kinda, 2007). Countries with larger economic size, lower inflation, low external debt and more developed financial markets minimize the economic and financial risks accordingly (Baslio, 2010). From the extant literature the following economic and financial variables are reported as 'triggers' of capital flows: real Gross Domestic Product (GDP) per capita and economic growth; the rate of inflation and international reserves; external debt and general government balance; fuel exports; and population (Eichengreen and Mody, 2000; Rose-Ackerman and Tobin, 2005; Basılio, 2010; Albalate et al., 2012).

Economies that have deregulated utility industries have witnessed an upward surge of private sector participation in infrastructure investments. Despite these reforms, the availability of a credit market in the host country represents an additional key factor to attracting private sector investors (Zagozdzon, 2013). Accessing capital via the credit market lowers investors' financial constraints and financing costs (c.f. Tobin and Brainard, 1963; Boyd and Prescott, 1986) and provides corporate governance by dealing with agency costs and informational asymmetries (c.f. Bernanke and Gertler, 1989). In turn, the market facilitates a pooling and sharing of risks posed. A weak credit market in developing countries poses a significant issue (Kleimeier and Versteeg, 2009). The size and depth of the local capital market (equity and debt) is much smaller, less liquid and has a narrower investor base. For this reason, private investors rely upon international capital markets for long-term finance to execute capital projects (Dailami and Leipziger 1998; Irving and Manroth, 2009). 
Various authors have demonstrated the importance of international economic conditions (or 'push factor') in determining private finance (c.f. Calvo et al., 1993). Key push factors may include: international interest rates; world growth rates; (Taylor and Sarno, 1997); and global liquidity as measured by the money supplies of key advanced economies (Ahmed and Zlate, 2013). A decline in the US interest rate may be a driving factor of private finance in developing countries, particularly those who are integrated into the international credit market (Dailami and Leipziger, 1998). For example, Kappeler and Nemoz (2010) in Yuan et al., (2012) provide evidence that the global financial crisis of 2008 had a disproportionately strong impact on the development of PPPs within developing countries. This was because private finance for PPP projects became more expensive and market capacity was substantially reduced, leading some commentators to claim that the PPP model was redundant. Based upon this synthesis of literature, the following hypotheses have been developed, namely that:

Hypothesis 2: The degree of private sector participation in energy infrastructure project delivery is positively related to business freedom.

Hypothesis 3: The degree of private sector participation in energy infrastructure delivery is positively dependent on the liquidity of the capital market.

Hypothesis 4: The degree of private sector participation in energy infrastructure delivery is positively dependent on: (H4a): trade openness; but negatively related to (H4b): fiscal burden. Hypothesis 5: The degree of private sector participation in energy infrastructure delivery is negatively related to the global interest rate.

\section{METHODOLOGY}

The deductive methodological approach adopted sought to prove hypotheses arising from extant literature using quantitative deterministic modeling techniques and secondary (independent variable) data sources. Secondary data were compiled from the World Bank Public-Private Infrastructure Advisory Facility (PPIAF); and Private Participation in Infrastructure (PPI) Project Database; Index of Economic Freedom (IEF); World Bank World Development Indicators (WDI) and Financial Development Database; and the Bank of Ghana annual financial statements. Time series data on forms of PPP contracts and the degree of private sector participation were obtained from the World Bank PPIAF and PPI Project Database over the period 1994 to 2013. These 
databases contain utility PPI project investment information (in millions of US\$) for telecommunications, energy, water and sewage, and transport projects per country. Importantly, the database registers private sector commitments to invest in public infrastructure (rather than actual disbursements) and therefore, tracks private sector intentions to invest. Because the database compiles information on predominantly large PPI projects, smaller projects are often omitted and hence, the total PPI quoted may not be accurate. Despite this omission, the database is the most complete source of PPI data across developing countries. Political and regulatory factors were obtained from the IEF whilst domestic/external economic and market conditions variables were sourced from World Bank WDI and financial development database, and the Bank of Ghana annual financial statements.

\section{Dependent Variables Degree of Private Sector Participation}

The degree of private sector participation is determined by the form of PPP contract chosen by the private investor and connotes private investors' risk appetite. The greater the investment commitment and ownership level, the higher the risk, which in itself determines a higher degree of intensity of participation. Therefore, a higher degree of participation in a particular form(s) of PPP contract is represented by a Boolean (binary) variable. Table 1 presents the project vehicle types, the intensity of private participation and associated Boolean coding.

\section{Independent Variables}

Independent variables are contained within two thematic groups, namely: i) infrastructure project characteristic variables; and ii) socio-political and economic variables. There are five infrastructure project characteristic variables, namely: i) degree of ownership and risks (OWN): measures the percentage of private investors' resource commitment into each energy project, ranging from 0 to $100 \%$; ii) size of investment (INVESTSIZE): measures the total amount of investment, in millions of U.S dollars, committed to the project; iii) project sector (SECT): a binary variable assigned a value of 1 if the project is a power sector project or 0 if the project is an oil and gas sector project; iv) project segment/network (SEGT): a binary variable assigned a value of 1 if the project is in generation segment or 0 if it is in transmission and distribution segment; and v) revenue source (REVSOURCE): a binary variable that assigned a value of 1 if the project has an identified revenue source or 0 if otherwise. With regards socio-political and economic variables, a 
further five variables were apparent, namely: i) business freedom (BFREED) index: provides an overall indicator of the efficiency of government regulation of business. The score ranges from 0 to 100, with 100 indicating the freest business environment; ii) fiscal freedom (FISCAL) index: provides a composite measure of the burden of taxes that reflects both marginal tax rates and the overall level of taxation, including direct and indirect taxes imposed by all levels of government, as a percentage of GDP. It is expressed on a scale of 0 to 100; iii) capital market development (CAPMKT): provides a measure of the ratio of stock market capitalization to GDP and rate of turnover in the stock market; iv) trade openness (OPENESS): provides the sum of imports and exports as a fraction of GDP to represent a measure of the country's receptiveness to foreign investment; and v) global interest rates (GLOBIR): usually approximated by the US Federal Funds rate, GLOBIR measures the opportunity cost of alternative investments.

\section{DATA ANALYSIS TECHNIQUES}

Inferential analysis was used to make generalizations about the wider population from the sample gathered and specifically to test hypotheses (Gabrenya, 2003; Baddie and Halley, 1995). Sample data collected sought to examine the relationship and differences between variables (Saunders et al., 2009). Significance testing was adopted to measure the probability that a pattern or relationship existing between the dependent and explanatory variables occurs by chance alone (Sirkin, 2005; Borror, 2009). Statistical significance was used to determine if a null hypothesis should be rejected or retained using probability values (or p-values) (Meier et al., 2011). Statistical significance is attained when a $p$-value is less than the significance level or alpha $(a)$ level (Redmond and Colton, 2001; Krzywinski and Altman, 2013; Sham and Purcell, 2014). Significance levels $\alpha=0.05$ (5\%), $\alpha=0.10(10 \%)$ and $\alpha=0.01(1 \%)$ were used for the analysis.

\section{Estimation Model}

The Binary Logistic Regression Model (BLRM) was adopted as a probabilistic statistical classification model to measure the relationship between the categorical dependent variable and independent variables. This econometric model was chosen because it is capable of accurately modeling a Boolean dependent variable. The product of calculations undertaken sought to determine which explanatory variables empirically influence the degree of private sector participation in energy infrastructure delivery. 


\section{Model Specification}

Logistic regression uses a linear regression to model the probability $p_{i}$ using a linear predictor function (LPF) $f(x)$ for a particular data point $i$ written as:

$$
f(x)=\beta_{0}+\beta_{1} x_{1, i}+\beta_{2} x_{2, i}+\cdots+\beta_{k} x_{i}
$$

Where $\beta_{0}, \ldots \beta_{m}$ are regression coefficients indicating the relative effect of a particular independent variable on the dependent variable. The logit model belongs to the class of binary response models that models a Boolean-valued outcome variable $Y_{i}$ for probability $p_{i}$ into the form:

$$
p_{i}=\operatorname{Pr}\left(Y_{i}=1 \mid \mathrm{X}\right)=F\left(\beta_{0}+\beta_{1} x_{1, i}+\beta_{2} x_{2, i}+\cdots+\beta_{k} x_{i}\right)
$$

Where $p_{i}$ is the probability of success; i.e. the probability of the outcome of 1 for trial $i ; F($.$) is$ the logistic distribution function taking on values strictly between zero and one: $0<\mathrm{G}(\mathrm{z})<1$ for all real numbers $\mathrm{z}$.

After estimating the model, the probability that $\mathrm{y}=1$ for each observation can be predicted. For the logit model, the probabilities are limited between 0 and 1 . The predicted probability indicates the likelihood of $y=1$. If the predicted probability is greater than 0.5 we can predict that $y=1$, otherwise $\mathrm{y}=0$. Equation 2 can be re-written as:

$$
\left.p_{i}=\operatorname{Pr}\left(Y_{i}=1 \mid \mathrm{X}\right)=\right) \frac{\exp \left(\beta_{0}+\beta_{1} x_{1, i}+\beta_{2} x_{2, i}+\cdots+\beta_{\boldsymbol{k}} x_{i}\right)}{1+\exp \left(\beta_{0}+\beta_{1} x_{1, i}+\beta_{2} \boldsymbol{x}_{2, i}+\cdots+\boldsymbol{\beta}_{k} \boldsymbol{x}_{i}\right)}
$$

Based on the model above, the predicted probability for the degree of private sector participation in energy infrastructure delivery is estimated as follows: 


$$
\begin{aligned}
p_{i} & =\operatorname{Pr}\left(Y_{i}=1 I \mathrm{X}\right)=F\left(\beta_{0}+\beta_{1} \text { OWN }+\beta_{2} I N V S I Z E+\beta_{3} \text { SECT }+\beta_{4} \text { SEGT }+\right. \\
& \beta_{5} \text { REVSOURCE }+\beta_{6} \text { BFREED }+\beta_{7} \text { OPNESS }+\beta_{8} \text { GLOBIR }+\beta_{9} F I S C A L+ \\
& \left.\beta_{10} \text { CAPMK }\right)
\end{aligned}
$$

\section{Parameter Estimation}

\section{Coefficients}

The coefficients returned from a logistic regression model are log-odds ratios. They indicate the log-odds of a 'success' change with a one-unit change in the independent variable. Increasing the log-odds of a success means increasing the probability that the dependent variable, $y=1$ (makes that outcome more/ less likely) and vice-versa - decreasing the log-odds of a success means decreasing the probability that $y=0$. Therefore, the sign of the log-odds ratio shows the direction of its relationship: $(+)$ means a positive relationship between $x_{i}$ and the likelihood of a success, and (-) means a negative relationship. The signs of the coefficient are interpreted but not the magnitude, as the latter cannot be interpreted using the coefficient because different models (linear probability, logit and probit) have different scales of coefficients.

\section{Odd Ratios (Relative Risk of the Logit Model)}

The odds ratios are the exponentiation of the coefficients and can be easier to interpret than the coefficient which is in log-odds units. The odd ratio is $p /(1-p)$ and measures the probability that $y$ $=1$ relative to the probability that $y=0$. For instance, a ratio of 2 means that the outcome $y=1$ is twice as likely as the outcome of $y=0$.

\section{Goodness of Fit Measures}

To measure the adequacy of a fitted logistic regression model, goodness of fit measures were employed:

\section{Percent correctly predicted}

The overall percentage gives the percent of cases where the dependent variables were accurately classified as either occurring or not occurring on the basis of our two-variable model. There is no 
absolute cut-off point which tells us whether or not this represents good fit but $100 \%$ represents a perfect fit.

\section{Hosmer-Lemeshow Test}

The Hosmer-Lemeshow (H-L) Test is akin to a Chi Square test, and indicates the extent to which the model fits the data, as in log-linear modeling. If insignificant, then the model has adequate fit and visa-versa. If the H-L goodness-of-fit test statistic is $>0.05$, the model estimates fit the data at an acceptable level. That is, well-fitting models show non-significance on the goodness-of-fit test. Akin to other significant tests, H-L determines whether the model fits or not but does not reveal the extent of the fit.

\section{(Pseudo) R Square}

(Pseudo) R Square is an approximation of the actual $R$ squared $\left(R^{2}\right)$ in linear regression, with its continuous dependent variables. The (Pseudo) $\mathrm{R}$ Square is developed to mimic $R^{2}$ for logistic regression models. There are a number of different Pseudo R Squares but for the purpose of this research the Nagelkerke's (Pseudo) $\mathrm{R}^{2}$ is used.

\section{RESULTS AND DISCUSSION OF PRIOR HYPOTHESIS}

Parameter estimates such as logistic coefficients, odd ratios, goodness of fit measures and probability scores were used to examine the significance, direction, magnitude and the overall fit of the relationships in the pattern of data. In all, ten variables (originally obtained from the extant literature) were identified as factors that determine the degree of private sector participation. Scientific Package for Social Scientists (SPSS) software was used to analyze the data and accompanying literature used to either accept or reject the various hypotheses previously formulated. Analyses are summarized and tabulated in Table 2. Logistic regression was performed to ascertain the effects of the independent variables on the degree of private sector participation. Model 1.1 reports estimates on infrastructure project characteristics variables only while Model 1.2 reports estimates on both infrastructure project characteristics variables and the socio-political and economic variables. 
From the results, the goodness-of-fit measures in Model 1.1 display an overall percentage of cases correctly predicted at around $76 \%$ but this rose to $81 \%$ in Model 1.2 . This means that $81 \%$ of the intensities of private sector participation have been accurately classified as either higher or lower, which is an improvement when the socio-political and economic variables were added to the infrastructure project characteristics variables. The H-L goodness-of-fit test statistic is insignificant and is greater than 0.05, indicating that the model's estimates fit the data an acceptable level. The Nagelkerke R-Squared reveals that about 14\% (Model 1.1) and 38\% (Model 1.2) of the proportion of the variation in the degree of private sector participation in both models can be explained by the independent variables. The predicted probability of Model 1.1 indicates that the infrastructure project characteristics variables alone can predict 0.79 of the model. However, when the socio-political and economic variables were added, the probability moved to 1 which illustrates that all the independent variables are key in predicting the likelihood of the private sector participating in higher forms of PPP. The high predicted probabilities reported upon in both models indicate that private investors pefer to invest in greenfield, concession and divestiture vehicles as opposed to management and leasing contracts. This may be because whilst such contractual arrangements are high risk, they also offer greater control over the work and a greater opportunity to generate higher profit margins.

From the main results, all the infrastructure project characteristics variables in Model 1.1 did not display significant coefficient estimates, except SEGT with a coefficient of $1.036(p=0.047)$. This indicates that the generation segment is more likely to influence the degree of private sector participation. By magnitude, SEGT is 2.817 times more likely to increase the degree of participation for every 1 percentage point increase in private investment in the project. However, when the socio-political and economic variables were added (see Model 1.2), project sector (SECT), which was insignificant in Model 1.1, becomes significant with a coefficient of $1.324(p$ $=0.082$ ). The SECT variable is 3.757 times more likely to influence private investment, which means that it is a critical consideration in the decision to participate in energy infrastructure delivery. The magnitude of influence of the SEGT in private investment is also increased to 3.586 times more likely. This confirms Hypotheses $1 c$ and $1 d$ that the degree of private sector participation is significantly dependent on SECT and SEGT respectively. 
Out of the five socio-political and economic variables added, three of them: i) business freedom (BFREED) index, ii) trade openness (OPENESS), and iii) global interest rates (GLOBIR) variables were significant at $(p=0.005 ; 0.011$ and 0.077$)$ respectively. The business freedom (BFREED) index, with a negative coefficient $(-0.280)$, shows an inverse relationship between the regulatory business enviroment and the extent of private participation, although a positive relationship was anticipated, therefore rejecting Hypothesis 2. An increase in BFREED index will reduce the extent of private participation by about $24 \%$ (odd ratio of 0.756 ) (refer to Table 2). The OPENESS variable on the other hand displayed a positive coefficient, indicating that a rise in trade openess index for Ghana is more likely to increase the receptiveness of foreign investment into the energy sector, satisfying Hypothesis $4 a$ that the degree of participation is positively dependent on trade openess. GLOBIR also displayed a positive coefficient signifying that a higher movement in the US federal funds rate is less likely to induce the degree of participation by 1.362 times in every 1 percentage point increase in the degree of private participation. However, this result is also not consistent with literature (Dailami and Leipziger, 1998; Calvo et al., 1993) that suggest that a decline in the US federal funds rates is a driving factor of private finance in developing economies, and vice versa. Hence, Hypothesis 5 was rejected.

\section{CONCLUSION}

Meeting the global demand for electricity consumption requires sustainable investments into building new, and maintaining (or upgrading/ replacing) existing, power sector infrastructure. Dealing with the deficit in energy infrastructure is a prerequisite to tackling the fundamental challenges to the economic growth of developing countries. However, mobilization of affordable finance and investment represents a significant challenge. Public funds and donor support have historically been inadequate, especially in jurisdictions where infrastructure provision is the primary responsibility of the prevailing government. For this reason, most economies have resorted to the private sector for delivering energy infrastructure projects, through PPP contracts. The infrastructure project's characteristics and the social-economic-political health of the host country have been determinants of private investment into the energy sector.

From extant literature, the paper identified five infrastructure project characteristics and five socio-

political and economic investment environment factors as determinants of the degree of investor 
participation. The study found out that there is a high probability that private investors pefer to invest in higher risk and potentially more profitable greenfield, concession and privatization vehicles vis-a-vis management and leasing contracts. None of the infrastructure project characteristics variables in Model 1.1 displayed significant coefficient estimates, except Project Segment/Network (SEGT), indicating that controlling for both transmission and distribution segments, the generation segment is more likely to influence the degree of private sector participation. Adding the socio-political and economic variables, however, changed the significance levels of the explanatory variables, with energy sector together with business freedom (BFREED) index, trade openness (OPENESS) and global interest rates (GLOBIR) variables becoming statistically significant.

New knowledge emanating from this paper provides crucial information on investment drivers to PPP advisors and project managers. Future research is however required to explore competitive routes to infrastructure debt and equity finance options that finance energy projects as well as measure the impact of any changes in government policy. In addition, the research needs to be extended to cover other developing nations in order to expand the application and impact of the findings. Whist the work is not a panacea to the energy infrastructure conundrum that developing nations are confronted with, it will engender future discussion amongst government policy makers responsible for promoting and managing PPP projects.

\section{ACKNOWLEDGEMENT}

We acknowledge World Bank Public-Private Infrastructure Advisory Facility (PPIAF) and Private Participation in Infrastructure (PPI) Project Database; Index of Economic Freedom (IEF); World Bank World Development Indicators (WDI) and financial development database; and the Bank of Ghana annual financial statements for the data used for the analysis. 


\section{REFERENCES}

Albalate, D., Bel, G. and Geddes, R. R. (2012) The Determinants of Contractual Choice for Private Involvement in Infrastructure Projects in the United States. Available via: http://www.ub.edu/irea/working papers/2012/201220.pdf [Accessed: August, 2014].

Alexander, I., Mayer, C. and Weeds, H. (1996) Regulatory Structure and Risk and Infrastructure Firms - an International Comparison, Policy Research Working Paper, the World Bank Ahmed, S., and Zlate, A., (2013) Capital Flows to Emerging Market Economies: A Brave New World? Board of Governors of the Federal Reserve System, International Finance Discussion Papers $\quad$ Number $1081 . \quad$ Available via: http://www.federalreserve.gov/pubs/ifdp/2013/1081/ifdp1081.pdf [Accessed: August, 2014].

Austvik, O. G. (2009) EU Natural Gas Market Liberalization and Long-term Security-of-supply and Demand. Available via: https://www.econbiz.de/.../eu-natural-gas-marketliberalization-and-long- [Accessed: November, 2014].

Baddie, E and Halley, F. (1995) Advantages in Social Research: Data Analysis Using SPSS for Windows, the Thousand Oaks. California: Pine Forge Press; a Sage Publications Company.

Badu, E., Edwards, D.J., Owusu-Manu, D. and Brown, D.M. (2012) Barriers to the Implementation of Innovative Financing (IF) of Infrastructure, Journal of Financial Management of Property and Construction, Vol. 17, No. 3, pp. $253-273$.

Balouga, J. (2012) The Political Economy of Oil Subsidy in Nigeria, International Association for Energy Economics. Available via: www.irjcjournals.org/ijmssr/July2013/13.pdf [Accessed: November, 2014].

Basılio, M. (2010) The Determinants of Private Sector and Multilateral Development Agencies Participation in Infrastructure Projects. Available via: http://www.stata.com/meeting/portugal10/portugal10 basilio.pdf [Accessed: July, 2014].

Bernanke, B. and Gertler, M. (1989) Agency Costs, Net Worth, and Business Fluctuations, American Economic Review, Vol. 79, No: 1, pp. 14-31.

Borror, C. M. (2009) Statistical Decision Making, the Certified Quality Engineer Handbook, 3rd Ed. Milwaukee, WI: ASQ Quality Press.

Boyd, J. H. and Prescott, E. C. (1986) Financial Intermediary-Coalitions, Journal of Economic Theory, Vol. 38, No. 2, pp. 211-232. 
Burns, P., and Riechmann, C. (2004) Regulatory Instruments and Their Effects on Investment Behaviour, World Bank Policy Research, Working Paper 3292, the World Bank. Available via:

https://openknowledge.worldbank.org/bitstream/handle/10986/14108/wps3292regulatory.p df?sequence $=1$ [Accessed: July, 2014].

Calvo, G., Leiderman, L. and Reinhart, C. (1993) Capital Inflows and the Real Exchange Rate Appreciation in Latin America: The Role of External Factors, IMF Staff Papers Vol. 40, on 2nd $\quad$ September, $2011 . \quad$ Available via: http://www.imf.org/external/pubs/ft/wp/2011/wp1109.pdf [Accessed: June, 2015].

Dailami, M. and Leipziger, D. (1998) Infrastructure Project Finance and Capital Flows: A New Perspective, World Development, Vol. 26, No. 7, pp. 1283-1298.

Demirag, I., Khadaroo, I., Stapleton, P and Stevenson, C. (2010) Public Private Partnership Financiers' Perceptions of Risks, the Institute of Chartered Accountants, Scotland. Available via:

https://www.academia.edu/956161/Public_Private_Partnership_Financiers_Perceptions of Risks [Accessed: September, 2014].

Devapriya, K.A.K. (2006) Governance Issues in Financing of Public Private Partnership Organizations in Network Infrastructure Industries, International Journal of Project Management Vo. 24, No. 7, pp. 557-565

Dua, P. and Garg, R. (2013) Foreign Portfolio Investment Flows To India: Determinants and Analysis, Centre for Development Economics, Working Paper No. 225. Available via: http://www.cdedse.org/pdf/work225.pdf [Accessed: June, 2014].

EC [European Commission] (2011), The Structuring and Financing of Energy Infrastructure Projects, Financing Gaps and Recommendations regarding the New Ten-E Financial Instrument Tender, Final Report, Directorate-General for Energy, Berlin/Brussels: Available via: http://ec.europa.eu/energy/infrastructure/studies/doc/2011 ten_e financing report.pdf [Accessed: November, 2014].

Eichengreen, B. and Mody, A. (2000) Lending Booms, Reserves and the Sustainability of ShortTerm Debt: Inferences from the Pricing of Syndicated Bank Loans, Journal of Development Economics, Vol. 63, No. 1, pp. 5-44. 
ESCAP [Economic and Social Commission for Asia and The Pacific] (2011) A Guide Book on Public-Projects in Construction. Available via: Lagosstateppp.Gov.Ng/Projects/Project_Portfolio/Project_In_Construction.Asp [Accessed: September, 2013].

Gabrenya, W.K. (2003) Inferential Statistics: Basic Concepts, In Research Skills for Psychology Majors: Everything You Need to Know to Get Started. Version: 1.0. Available via: my.fit.edu/ gabrenya/IntroMethods/eBook/inferentials.pdf [Accessed: January, 2013].

Grimsey, G. and Lewis, M. K. (2002) Evaluating the Risks of Public Private Partnerships for Infrastructure Projects, International Journal of Project Management, Vol. 20, No. 2, pp. 107-118.

Hammami, M., Ruhashyankiko, J., and Yehoue, E. B. (2006) Determinants of Public-Private Partnerships in Infrastructure, IMF Working Paper, WP/06/99. Available via: https://www.imf.org/external/pubs/ft/wp/2006/wp0699.pdf [Accessed: 15th July, 2014].

IBRD/World Bank [The International Bank For Reconstruction And Development / The World Bank] (2009) Attracting Investors To African Public-Private Partnerships: A Project Preparation Guide, ISBN 978-0-8213-7731-4.

Irving, J. and Manroth, A. (2009) Local Sources of Financing for Infrastructure in Africa: A CrossCountry Analysis, Policy Research Working Paper 4878, The World Bank Africa Region, African Sustainable Development Front Office. Available via: http://www.iea.org/publications/freepublications/publication/english.pdf $\quad$ [Accessed: November, 2014].

Ismail, S. (2013) Factors Attracting the Use of Public Private Partnership in Malaysia, Journal of Construction in Developing Countries, Vol. 18, No. 1, pp. 95-108.

Jamasb, T. and Pollitt, M. (2005) Electricity Market Reform in The European Union: Review Of Progress Toward Liberalization \& Integration, The Energy Journal, Vol. 26, No. 201, pp. $11-41$.

Joskow, P. L. and Schmalensee, R. (1983) Markets for Power: An Analysis of Electrical Utility Deregulation. Available via: https://books.google.com.gh/books?isbn=0521893135 [Accessed: January, 2015].

Kappeler, A., and Nemoz, M. (2010) Public Private Partnerships in Europe-Before and during the Recent Financial Crisis. European Investment Bank Economic and Financial Report. 
Available via: http://www.eib .org/attachments/efs/efr 2010 v04 en.pdf [Accessed: March, 2014].

Kerf, M., Gray, R. D., Irwin, T., Levesque, C., and Taylor, R. R. (1998) Concessions for Infrastructure: A Guide to their Design and Award, World Bank Technical Paper 399. Washington DC: The World Bank.

Kinda, T. (2007) Financial Innovations, MPRA Paper No. 19163. Available via: http://mpra.ub.uni-muenchen.de/19163/ [Accessed: July, 2015].

Kirkpatrick, C and Parker, D. (2004) Infrastructure Regulation: Models for Ddeveloping Asia. Research Paper series No. 60, November 2004, ADB Institute.

Kleimeier, S. and Versteeg, R. (2009) Project Finance as a Driver of Economic Growth in LowIncome Countries, Review of Financial Economics, Vol. 19, No. 2, pp. 49-59.

Krzywinski, M. and Altman, N. (2013) Points of Significance: Significance, P Values and t-tests, Nature Methods (Nature Publishing Group), Vol. 10, No. 11, pp. 1041-1042.

Meier, K. J., Brudney, J. L. and Bohte, J. (2011) Applied Statistics for Public and Nonprofit Administration, 3rd Ed. Boston MA: Cengage Learning.

Mody, A., Taylor, M.P. and Kim J.Y. (2001) Modeling Economic Fundamentals for Forecasting Capital Flows to Emerging Markets, International Journal of Finance and Economics, Vol. 6, No.3, pp. 201-216.

Moszoro, M. and Krzyzanowska, M. (2007) Striving for the Quality of Public Services through Public-Private Partnerships: The Case of 7 Projects in The City of Warsaw. Available via: http://ssrn.com/abstract=1146965, www.wsb-nlu.edu.pl, [Accessed: August, 2014].

Newbury, D. (2000) Privatization, Restructuring and Regulation of Network Utilities. Available via: https://books.google.com.gh/books?isbn=1781950954 [Accessed: September, 2014].

Noll, R. G. (2000) Progress in Telecommunications Reform in Mexico, Background Paper prepared for the "Country Framework Report on Infrastructure in Mexico", The World Bank, Washington DC. Available via: http://web.worldbank.org/archive/website00894A/WEB/PDF/CHAPTE-7.PDF [Accessed: November, 2014].

OECD [Organization for Economic and Cooperation Development] (2012),Mapping Support for Africa's Infrastructure Investment, Final Report, OECD. Available via: 
March, 2014].

Ogunsanmi, O. E. (2014) Critical Success Factors (CSF) Determining the Implementation of Public-Private Partnership Projects, Covenant Journal of Research in the Built Environment (CJRBE), Vol. 1, No. 2, pp. 41-63.

Owusu-Manu D., Badu E. and Edwards D.J. (2008) Conceptual Paradigm and Rethinking Project Finance Strategy for Highway Projects Financing in Ghana, PentVars Business Journal, Vol. 3, No. 3, pp. 85-93.

Pargal, S. (2003) Regulation and Private Sector Investment in Infrastructure: Evidence from Latin America, World Bank Policy Research Working Paper 3037. Available via: http://elibrary.worldbank.org/doi/pdf/10.1596/1813-9450-3037 [Accessed: November, 2014].

Parker, D. and Hartley, K. (2003) Transaction Costs, Relational Contracting and Public Private Partnerships: A Case Study of UK Defense, Journal of Purchasing and Supply Management. Vol. 9, No.3, p.p. 97-108.

Peirson, P. and McBride, P. (1996) Public/Private Sector Infrastructure Arrangements, CPA Communiqué; Vol. 73, pp. 1-4.

Pessoa, A. (2008) Public-Private Partnerships In Developing Countries: Are Infrastructures Responding to the New ODA Strategy? Journal of International Development, Vol. 20, No. 3, pp. 311-325.

Pistor, K., Raiser, M. and Gelfer, S. (2000) Law and Finance in Transition Economies, Economics of Transition, Vol. 8, No. 2, p.p. 325-368.

PSIRU [Public Services International Research Unit] (2012) Financing Water and Sanitation: Public Realities, A Report for Public Services International for the Sixth World IWater Forum, Marseille: PSIRU.

Redmond, C. and Colton, T. (2001) Clinical Significance versus Statistical Significance, Biostatistics in Clinical Trials, Wiley Reference Series in Biostatistics, 3rd Ed. John Wiley and Sons Ltd: West Sussex, United Kingdom.

Rose-Ackerman, S. and J. Tobin (2005) Foreign Direct Investment and the Business Environment in Developing Countries: The Impact of Bilateral Investment Treaties, Yale Law \& Economics, Research Paper No. 293. 
Saunders, M., Lewis, P. and Thornhill, A. (2009) Research Methods for Business Students, 5th Ed. London: Pearson Education Ltd.

Sham, P. C. and Purcell, S. M. (2014) Statistical Power and Significance Testing in Large-Scale Genetic Studies, Nature Reviews Genetics (Nature Publishing Group), Vol. 15, No. 5. pp. $335-346$.

Sirkin, R. M. (2005) Two-sample t tests, Statistics for the Social Sciences, 3rd ed, Thousand Oaks, CA: SAGE Publications, Inc.

Smith, W. (1997) Utility Regulators - the Independence Debate, Viewpoint 127, the World Bank, Washington DC. Available via: http://rru.worldbank.org/viewpoint/HTMLNotes/127/127smith.pdfSmith [Accessed: January, 2014].

Taylor, M.P. and Sarno, L. (1997) Capital Flows to Developing Countries: Long- and Short- Term Determinants, World Bank Economic Review, Vol. 11, No. 3, pp. 451-71.

Tobin, J. and Brainard, W. (1963) Financial Intermediaries and the Effectiveness of Monetary Control, American Economic Review, Vol., No. 53, pp. 383-400.

Tohmatsu, D. T. (2003) Sustainable Power Sector Reform in Emerging Markets: Financial Issues and Options, Joint World Bank/USAID Policy Paper. Available via: http://pdf.usaid.gov/pdf docs/PNADB308.pdf [Accessed: January, 2015].

UNECA [United Nations Economic Commission for Africa] (2011) Strengthening Public-Private Partnerships in the Electricity Sector in West Africa. Available via: http://41.138.49.23/observatoire/documentation/PPPElectricSector_ENG_SROWA 31\%2007\%202013.pdf [Accessed: August, 2014].

Woodhouse, E. J. (2005) A Political Economy of International Infrastructure Contracting: Lessons from the IPP Experience, Working Paper No. 52, 27. Available via: http://pesd.fsi.stanford.edu/sites/default/files/PESD IPP Study\%2C Global Report.pdf [Accessed: January, 2015].

World Bank (2011) Africa Infrastructure Knowledge Program: Handbook on Infrastructure Statistics. Available via: http://www.infrastructureafrica.org/ [Accessed: May, 2014].

World Bank (1994) Infrastructure for Development, World Development Report, The World Bank. 
Yuan, J., Wang, C., Skibniewski, M. J. and Li, Q. (2012), Developing Key Performance Indicators for Public-Private Partnership Projects: Questionnaire Survey and Analysis, Journal of Management in Engineering, Vol. 28, No. 3, pp. 252-264.

Zagozdzon, B. (2013) Determinants of Implementation of Public-Private Partnership in Poland: The Case of Transport Infrastructure, Advances in Economics and Business, Vol.1, No.2. pp. $57-71$. 
Figure 1 - Risk compared to participation for PPP contracts: a theoretical construct

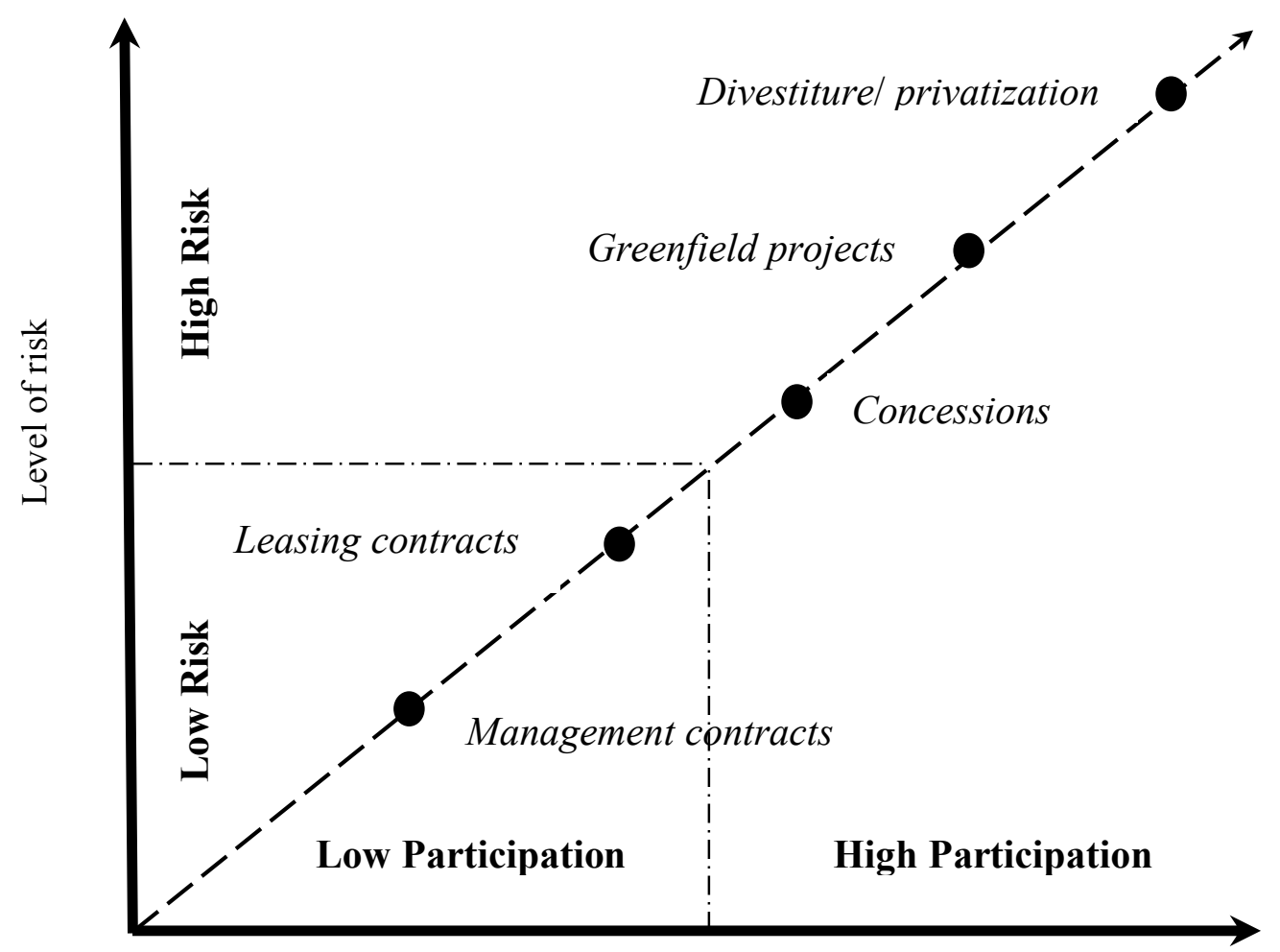

Level of investor participation 
Table 1 - Degree of Private Sector Participation

\begin{tabular}{ccc}
\hline Project Vehicle Types & $\begin{array}{c}\text { Intensity of Private } \\
\text { Participation }\end{array}$ & Boolean Coding \\
\hline Concession/Greenfield/Privatization & Very High & 1 \\
Management/Leasing Contracts & Very Low & 0 \\
\hline
\end{tabular}


Table 2 - Summary of Analysis

\begin{tabular}{|c|c|c|}
\hline Independent variables & Model 1.1 & Model 1.2 \\
\hline \multirow[t]{2}{*}{ OWN } & $0.005(0.014)$ & $-0.009(.018)$ \\
\hline & 1.005 & 0.991 \\
\hline \multirow[t]{2}{*}{ INVSIZE } & $-0.001(0.002)$ & $0.002(0.002)$ \\
\hline & 0.999 & 1.002 \\
\hline \multirow[t]{2}{*}{ SECT } & $1.169(0.605)$ & $1.324(0.760)^{*}$ \\
\hline & 3.219 & 3.757 \\
\hline \multirow[t]{2}{*}{ SEGT } & $1.036(0.522) * *$ & $1.277(0.641)^{* *}$ \\
\hline & 2.817 & 3.586 \\
\hline \multirow[t]{2}{*}{ REVSOU } & $0.019(0.618)$ & $-0.168(0.701)$ \\
\hline & 1.019 & 0.845 \\
\hline \multirow[t]{2}{*}{ BFREED } & & $-0.280(0.100) * * *$ \\
\hline & & 0.756 \\
\hline \multirow[t]{2}{*}{ OPNESS } & & $4.405(1.736) * *$ \\
\hline & & 81.836 \\
\hline \multirow[t]{2}{*}{ GLOBIR } & & $0.0309(0.175) * * *$ \\
\hline & & 1.362 \\
\hline \multirow[t]{2}{*}{ FISCAL } & & $0.026(0.052)$ \\
\hline & & 1.026 \\
\hline \multirow[t]{2}{*}{ CAPMKT } & & $0.113(0.127)$ \\
\hline & & 1.120 \\
\hline \multirow[t]{2}{*}{ Constant } & $-1.154(1.602)$ & $7.780(6.079)$ \\
\hline & 0.315 & 2393.34 \\
\hline $\mathbf{N}$ & 10 & 10 \\
\hline Percent correctly predicted & $76 \%$ & $81 \%$ \\
\hline Hosmer and Lemesnow Chi Square test & 6.638 & 3.978 \\
\hline (Nagelkerke) R-Squared & 0.141 & 0.381 \\
\hline $\operatorname{Pr}(Y=1)$ & 0.79 & 1 \\
\hline
\end{tabular}

